\title{
Strateji Uygulamalarına Etki Eden Faktörler ve Bu Faktörlerin Performans Üzerine Etkisi: Türkiye'deki Ticari Bankalar Üzerine Bir Araştırma*
}

\author{
M. Atilla ARICIOĞLU ${ }^{1}$, Şükran GÖKCE ${ }^{2}, \quad$ Mehmet Nuri SALUR ${ }^{3}$ \\ ${ }^{1}$ Necmettin Erbakan Üniversitesi, Siyasal Bilgiler Fakültesi, İşletme Bölümü \\ ${ }^{2}$ Sakarya Üniversitesi, Sosyal Bilimler Enstitüsü, Doktora Öğrencisi \\ ${ }^{3}$ Necmettin Erbakan Üniversitesi, Siyasal Bilgiler Fakültesi, İşletme Bölümü
}

\begin{abstract}
Özet
Strateji ve stratejik yönetim günümüzün hızla değişen küresel ekonomisi ve iş ortamında işletmelerin yaşamaları ve bu yaşamlarını sürdürülebilir kılmalarını sağlayan önemli bir yönetim aracıdır. Çevrede meydana gelen bu hızlı değişimlere entegre olabilmek işletmelerden yüksek düzeyde üretkenlik hızı ve esneklik talep etmektedir. Bu talepleri karşılayabilmek adına işletmeler gerek örgüt yapılarını gerekse iş yapma biçimlerini stratejik olarak değiştirmelidirler. Yapılan son araştırmalar da bu sonucu destekler biçimde rekabetçi pazarlarda etkin bir strateji uygulamanın başarılı işletmeleri başarısız olanlardan ayıracak en önemli faktör olduğunu ortaya koymaktadır. Bu araștırmanın temel amacı Türkiye'deki bankalarda strateji uygulamasına etki eden temel faktörleri analiz etmektir. Özellikle iletişim sistemleri, örgüt kültürü, örgüt yapısı ve liderlik tarzının bankalarda strateji uygulamasını etkileyip etkilemediğini ve etkiliyorsa bunun göreceli önemini ortaya koymaktır. Bu amaçla 28 bankanın üst-orta ve alt kademe yöneticileriyle 167 anket yapılmış, sonuçlar analiz edilmiş ve yorumlanmıştır.
\end{abstract}

Anahtar Kelimeler: Strateji uygulama, iletișim sistemleri, örgüt kültürü, örgüt yapısı ve liderlik tarzı.

\section{Factors Affecting Strategy Implementation and the Impact of These Factors on Performance: A Research on Commercial Banks in Turkey}

\begin{abstract}
Strategy and strategic management is an important management tool in todays'srapidly changing global economy and business environment, enabling businesses to make their lives sustainable. Being able to integrate with these rapid changes in the environment demands a high level of productivity speed and flexibility from businesses. In order to meet these demands, businesses and organizations must strategically change their way of doing business. Recent research suggests that effective strategy implementation in competitive markets such as these endorsements is the most important factor to distinguish successful businesses from unsuccessful ones. The main purpose of this research is to analyzethe main factors affecting the strategy implementation in the banks in Turkey. In particular, communication systems, organizational culture, organizational structure and leadership style influence the implementation of strategies in banks and if the affect, it is of relative importance. For this purpose, 167 questionnaires were conducted by the upper, middle and lower level managers of 28 banks and the results were analyzed and interpreted.
\end{abstract}

Keywords: Strategy implementation, communication systems, organizational culture, organizational structure and leadership style.

${ }^{*}$ Bu çalışma Necmettin Erbakan Üniversitesi Bilimsel Araştırma Projeleri Koordinatörlüğü tarafindan desteklenmiştir.

\section{Giris}

Strateji uygulama işlevi strateji geliştirmek ve hedeflenen performansa ulaşmak için neler yapılması gerektiğinden ibarettir. Stratejik yönetim literatüründe strateji belirleme kısmına yapılan katkının uygulamadan daha fazla olduğunu belirtmek gerekir. Oysa uygulamanın etkin bir şekilde yerine getirilememesi en iyi şekilde formüle edilen stratejiyi bile işe yaramaz hale getirecektir. Stratejilerin başarıyla uygulanması, gerek özel gerekse kamusal alanda faaliyet gösteren örgütler için çok önemlidir. Söz konusu örgütlerin birçoğu stratejilerini uygulamaya aktarmakta zorluk çekmektedirler (Alashloo vd. 2005: 54). Araştırmacıların bu tespiti nicel verilerle de desteklenmektedir. Nitekim Popüler Fortune araştırmaları iyi formüle edilmiş stratejilerin \%10'undan daha azının etkin bir şekilde uygulandığını ortaya koymakta (Rumelt, 2011: 33); diğer bir çalışma olan The Times 1000'de, yöneticilerin \%80'i doğru stratejilere sahip olduklarını ifade ederken, bunlardan sadece \%14'ü stratejilerin iyi bir şekilde uygulandığını düşünmektedir (Cobbold ve Lawrie G. 2002: 2). Okumuş, uygulamaların başarısız olmasının temel sebebi olarak yöneticilerin uygulama sırasında eylemlerine yol gösterecek pratik modellerin olmamasını gösterir. Yöneticiler yeterli modeller olmadan temel faktörleri iyi kavramadan stratejileri uygulamaya çalışmaktadırlar (Okumuş, 2003: 876).

\section{Kavramsal Cerçeve \\ 2.1. Strateji Uygulama}

Alexander (1985) stratejik yönetim sürecini ikiyüzlü madalyona benzetir. Bir yüzü özel durumlarda başarılı bir şekilde rekabet edebileceği oyun planını ortaya koyan strateji formülasyonu, diğer yüzü ise formüle edilen bu stratejinin finans, insan kaynakları ve zaman kısıtı altında nasıl hayata geçirileceğini açıklayan strateji uygulama sürecidir- Stratejik yönetimin "strateji ne olmalı ve nasıl uygulamaya konulmalı" sorularına birlikte cevap vermektedir. Ancak analiz ve sentezi içeren strateji formülasyonun aksine, strateji uygulama bilimden ziyade sanat olarak görülür; parçalı ve eklektik olarak tarif edilir (Noble, 1999: 120); entellektüel ve yaratıcı yetenekleri gerektirir (Joubert, 1988: 19). Çünkü tutarlı bir strateji formülasyonuna rağmen tüm örgütte strateji çalışmalarını yürütmek oldukça zordur. Ayrıca unutmamak gerekir ki stratejik planları eyleme dönüştürme sürecini sayısız faktör etkileyebilir. Bu karmaşık, zor ve zaman alıcı bir süreci işaret eder (Thompson ve Strickland, 2003: 178). 
Nitekim Hambrick ve Cannella (1989) başarılı bir uygulama olmadan stratejinin fanteziden öteye gidemeyeceğini; iyi bir strateji uygulamasının pazarda lideri oyunculardan ayıracağını bir başka ifade ile başarı ya da başarısızlığı belirleyenin uygulama olduğunu ifade eder. Schaap'a (2006) göre strateji uygulama şirketlerin gelecekteki firsatları tanımladıkları; birçok değişkene bağlı olan son derece karmaşık, etkileşimli ve canlı bir süreçtir. Noble (1999) için strateji uygulama stratejik niyeti eylemlere dönüştüren yönetsel müdahaleleri ifade eder. Singh (1998) strateji uygulamayı karar verilmiş, formüle edilmiş stratejiyi oluşturan faaliyetlerin adım adım yerine getirilmesidir ve bilişsel bir süreç olarak tanımlarken, Hitt ve arkadaşları (2007) için strateji uygulama, örgütün seçtiği stratejiyi harekete geçirmek için uygun organizasyon yapılarını ve kontrol sistemlerini tasarlamaktır.

Ortaya çıkan tanımlar üç farklı görüşü öne çıkarmaktadır: İlki süreç perspektifinden yaklaşır ve strateji uygulamayı dikkatlice planlanmış ardışı adımlar dizisi olarak tanımlar. İkincisi daha fazla ya da daha az uyumlu ancak paralel bir dizi eylem ve uygulamalar ile bu eylemlerin davranış açısından incelenmesini irdeler. Üçüncü yaklaşım hibrit perspektifinden yola çıkarak, strateji uygulamayı stratejik hedeflere ulaşmak için bir dizi iç ve diş faktörlerden etkilenen, yöneticiler ve çalışanlar tarafından alınan kararlar ve faaliyetlerden oluşan karmaşık, tekrarlamalı ve dinamik bir süreç olarak ele alır.

\subsection{Strateji Uygulamasına Yönelik Temel Faktörler}

Stratejinin uygulanmasının içerdiği farklılıklar, yapısal sorunlar ve örgüt çalışanları dikkate alındığında kolay bir durum içermediği anlaşılır (Kamanda, 2006: 187). Otiso'ya (2008: 27) göre, farklı paydaşları koordine etme ve ortak hedefe yönelik eylemlerini uyumlu hale getirme süreci birçok zorluklarla karşı karşıyadır. Uyumu sağlayacak ve uygulamada kullanılacak temel faktörler şunlardır: Liderlik stilleri, iletişim sistemi, organizasyon kültürü ve organizasyon yapısı.

\subsubsection{Liderlik Tarzı}

Cater ve Pucko (2010)'a göre, iyi formüle edilmiş bir strateji, güçlü ve etkin bir beceri havuzu ve insan sermayesi strateji uygulamanın başarısı için son derece önemli kaynaklar iken zayıf liderlik başarılı bir uygulamanın önündeki en önemli sorunlardan biri olarak gösterilmektedir. Buna karşılık liderlik aynı zamanda etkin bir strateji uygulaması için itici bir güçtür. Başarılı bir strateji uygulamasında temel zorluk, yeni bir strateji karşısında çalışanların iş anlayışları ve yeteneklerini bu doğrultuda yönlendirmeleri ve desteklemelerinin sağlanmasıdır. $\mathrm{Bu}$ nedenle etkin lider ihtiyacı diğer faktörlerden daha ağır basar. Beer ve Eisenstat (2000: 31) bu sorunu farklı bir perspektiften ele alarak, etkili liderliğin yokluğunda çatışan önceliklerin çalışanlar arasında zayıf uyuma sebep olacağını ifade eder, çünkü bireyler potansiyel tehditlerden ve utanç verici durumlardan sakınmak için tepe yönetiminin tercihlerine şüpheyle yaklaşacaktır.

Görüldüğü gibi üst düzey yöneticilerin liderliği etkin bir strateji uygulamasına engel teşkil eden en önemli faktörlerden ve etkin bir uygulamanın anahtar kavramlarından birisi olarak tanımlanmaktadır (Noble 1999: 123; Hrebiniak 2005: 68).
Nitekim stratejik liderliği, örgüt için gerçekleştirilebilir bir gelecek yaratacak değişiklikleri başlatmak için geleceği görme, vizyon oluşturma, esnekliği sağlama, stratejik olarak düşünme ve diğerleri ile çalışabilme becerileri olarak tanımlayabiliriz. Buna göre, stratejik liderlik süreçlerinin rakipler tarafindan anlaşılması ve taklit edilmesi güç olduğunda firma rekabetçi bir avantaj elde etmiş olur. Pearce ve Robinson (2003: 39), stratejik yönetimin katalizörünün CEO olduğunu ve bir stratejinin başarısı ile en yakından tanımlanan ve en nihayetinde sorumlu olan kişi olduğunu iddia etmektedir. Freedman ve Tregor (2003: 24)'da, strateji uygulamasının başarılı olup olmayacağının sonuçta örgütün stratejik liderlerinin stratejik değişim sürecini hazırlama konusundaki isteksizliğine ya da beceriksizliğine bağlı olacağını savunmaktadır.

Araştırmacılar ayrıca stratejilerin uygulanmasında farklı düzeylerdeki liderliğin etkisini de incelemişlerdir. O'Reilly ve ark. (2010) farklı düzeylerdeki liderlerin etkinliğinin stratejilerin uygulanmasi sirasinda önemli performans artışlarına yol açtığı görülmüştür. Uygulama bazı şeyleri doğrudan bazılarını ise dolaylı yollarla değiştirebilir.

Birçok çalışma ise liderlik tarzının çalışanların strateji uygulama sürecine katılımı üzerindeki etkisine dikkat çekmektedir, çünkü örgütün her düzeyinde strateji algısını belirleyen stratejik ilkeleri ve kuralları tanımlamaktan sorumlu olan kişilerdir (Boomer, 2007: 63). Dolayısıyla yönetimin görevi strateji ile çalışanların günlük eylemleri arasındaki uçurumu ya da boşluğu ortadan kaldırmak bunun yanı sıra belirlenmiş olan stratejik yönün izlenmesi ile örgütsel sorunlar arasında etkin bir iletişimi amaçlayan eylemler gerçekleştirmektir.

Diğer taraftan yöneticilerin strateji uygulamada başarısız olmalarının kaynağı olarak kontrolsüz karar verme, yanlış alg1 ve bunlarla ilgili konuları işaret etmektedir (Mezias ve Starbuck, 2003: 6). Ayrıca yazar istenen davranışların geliştirilmesinde, bireysel sahipliğin teşvik edilmesinde ve uyumlu bir zihinsel model yaratılmasında liderlerin görevine vurgu yapmıştır. Ona göre, strateji yaratıcıları ve uygulayıcıları ile diğer çalı̧̧anlar arasında hayali bir çizgi vardır ve strateji formülasyonu sıklıkla yaratıcı bir görev olarak algılanır dolayısıyla tepe yöneticisinin göreviymiş gibi düşünülür. Oysaki Foster ve Browne (1996: 47) uygulamanın genellikle orta düzey yöneticilere devredilen bir alan olduğunu ifade etmişlerdir. Dolayısıyla liderlerin görevi strateji uygulamada ortak bir amaç etrafinda toplanmak adına bu hayali çizgiyi (informal bölünmeyi) ortadan kaldırmaya yönelik tedbirleri almaktır (Radomska, 2014: 216). Ayrıca belirtmek gerekirse stratejik liderlik aynı zamanda etik uygulamaları vurgulamayı da içerir. Etik uygulamalar, olası eylem adımlarının değerlendirildiği ahlaki bir filtre işlevi görür (Smith, 1995: 690).

Sonuç olarak bir örgütteki liderlik tarzı seçilen stratejilerin nasıl uygulanacağını etkiler. Örgüt yapısı, yetki devri, karar verme, teşvik ve ödül sisteminde yöneticinin özgürlüğü o örgüt içindeki liderlik tarzının etkisinde olacaktır. Burada dikkat edilmesi gereken en önemli nokta yukarıda sayılan tüm parametrelerin örgütte stratejilerin başarılı bir şekilde uygulanmasında esas olmasıdır.

\subsection{2. Örgüt Kültürü}

Stratejik yönetim; stratejilerin belirlenmesi, uygulanması ve kontrol aşamalarının tamamında örgüt kültürünün 
etkisinde kalacak ve örgüt kültürü de stratejik yönetimin işleyişi üzerinde belirleyici bir etkide bulunacaktır. Örgüt kültürü yöneticilerin liderlik tarzını, zamanlarını nasıl harcadıklarını, çalışanlardan ne talep ettiklerini, ne üzerinde yoğunlaşıklarını ve nasıl karar aldıklarını anlatır. Ancak unutmamak gerekir ki lider kadar çalş̧anlarda süreçte rol oynarlar. Nitekim, çalışanların strateji uygulama sürecine katılımları sağlanarak vizyon, değerler ve strateji ile uyumlaştırılması, bu yolla ortak vizyonun uygulanmasının gerçek sonuçlarını algılanmaları sağlanabilecektir. Tüm bu eylemlerin örgüt kültürüne etkin bir şekilde uyumu da oldukça önemlidir (Varon, 2002: 18).

Örgütün zengin ve baskın olan kültürü strateji belirlemede, belirlenen stratejinin uygulanmasinda etkin bir faktör olmaktadır. Bu nedenle de bazı strateji araştırmacıları nihai olarak örgüt kültürünün strateji ve örgüt yapısından daha önemli olduğu fikrini savunmaya başlamışlardır (Sarvan vd, 2003: 89) Örgüt kültürü var olan stratejiyi destekler ancak, stratejik değişimin karşısındaki en önemli sınırlayıcılardan biri de örgüt kültürü olabilmektedir.

$\mathrm{Bu}$ durum, stratejik hedefler ile örgütün ilkeleri ve değerleri arasındaki tutarlılığın, özellikle yönetsel eylemler bağlamında ve uygulama stratejisi için kritik olduğunu belirtmektedir (Sabourin, 2012: 54). Örneğin, Ahmadi, Salamzadeh, Daraei ve Akbari (2012) İran bankalarında strateji uygulanmasinda örgüt kültürünün etkisini incelemişler ve kültür ile uygulama arasında anlamlı bir ilişki olduğu sonucuna varmışlardır. Latin Amerika firmalarını kapsayan bir çalışmada Brenes ve Mena (2008), yeni stratejinin değer ve ilkelerini destekleyen bir örgütsel kültürün işletmelerde stratejilerin başarılı bir şekilde uygulanmasına yol açtığını ifade etmektedirler. Ayrıca en başarılı işletmelerin \%86'sında kültürle stratejinin uyumlu olduğu buna karşıllık daha az başarılı işletmelerde bu oranın $\% 55$ ’e düştüğü görülmektedir.

\subsection{3. İletişim}

Strateji formüle edildikten sonra, iletişim stratejinin başarıyla uygulanması için gerekli en önemli araçlardan birisidir. Her şeyden önce yönetim, yeni stratejinin içeriği, anlamı ve sebepleri hakkında tüm çalışanları bilgilendirmelidir. Bununla birlikte, yalnızca çalışanları bilgilendirmemeli, ayrıca çalışanlara karar hakkı-insiyatif bırakmalıdır. İletişim aynı zamanda stratejiden etkilenecek olan çalışanlara yeni görev ve sorumlulukların açıklanmasını da içerir.

Uygulama süreci boyunca, yönetimin uygulama sürecini izlemesi ve yaklaşımda değişikliklere ihtiyaç duyulup duyulmadığına karar vermek için iletişimin aşağıdan yukarıya akması gerekir (Alexander, 1985: 91). Kararlara hem yöneticilerin hem de çalışanların dâhil olması ve başarılı bir şekilde uygulanabilmesi için tüm taraflar arasındaki iletişimin korunması önemlidir. Uygulama etkinliği çatışmalardan olumsuz, iletişimden özellikle de kişilerarası sözsel iletişimden olumlu etkilenir (David, 2007:14). Harrington (2006: 375), strateji uygulama sürecinde örgütsel katılım düzeyinin yüksek olmasının hem uygulama başarısı üzerinde hem işletme karı hem de genel işletme başarısı üzerinde pozitif etkiye sahip olduğunu ifade etmektedir. Lares-Mankki (2014) 862 sigorta şirketi çalışanı üzerinde yaptığı çalı̧̧masında üst yönetimin uygulamalarının iş doyumu, çalışanların bağlılı̆̆ı ve rol belirsizliği üzerindeki etkilerini analiz etmiştir. $\mathrm{Bu}$ çalışmada beş yönetim uygulaması analiz edilmiştir; Yaratıcılığın teşvik edilmesi, örgütsel bir amaç yaratma ve paylaşma, çalışanlara destek verme, bir model rolü oynamak ve işle ilgili kararlar almaya çalışanların katılımını sağlamak. Çalışma sonuçları, üst yönetimin eylemleri ile çalışanların tutum ve algıları arasında güçlü bir ilişki bulunduğu vurgulanmıştır. Kurumsal iletişim ve strateji uygulama üzerine yapılan keşifsel bir araştırmada Forman ve Argenti (2005: 260) işletme içi iletişimin yalnızca stratejinin oluşturulmasında değil aynı zamanda stratejinin başarıyla uygulanmasında önemli bir yere sahip olduğunu tespit etmiştir.

\subsection{4. Örgüt Yapısı}

Doğru bir örgüt yapısı, örgütün stratejisini uygulamasına olanak tanıdığı için önemlidir. Burada sorulması gereken temel soru: arzulanan geleceği başarılı bir şekilde ortaya koymada organizasyon yapısı nasıl olmalıdır ve süreçle birlikte bu yapı nasıl bir yol izlemelidir?

Chandler (1962) örgüt yapısının örgüt stratejileri tarafından etkilendiğini öne sürer (yap1 stratejisini izler). Zaribaf ve Bayrami (2010)'ın araştırma sonuçları Chandler'inkiyle uyumludur. Yazarlar stratejinin sadece üst yönetim tarafindan formüle edildiğini ve orta düzey yöneticilerin uygulamadan önce önemli ölçüde değişiklikler gerekli görülmedikçe sadece uygulamadan sorumlu tutulduklarını ifade ederler.

Lepsinger'in (2006) çalışmasında ise cevaplayıcıların önemli bir kısmı örgütsel yapı faktörünü strateji ile uygulama arasındaki boşluktan sorumlu temel bir unsur olarak ifade etmişlerdir. Getz ve Lee (2011: 306) ise strateji ile uyumlu bir örgütsel yapının gerekliliğine vurgu yapmışlardır. İşletme ve örgüt yapısı büyüdükçe proje grupları, iş birimleri ve bireysel departman düzeyinde çalş̧anların stratejik uygulamaya katılım düzeyi daha yüksek olacaktır. Büyük ve daha karmaşık bir örgütsel yap1 orta ve operasyonel düzeydeki yöneticilerin daha fazla katılımını gerektirir. Doğru bir örgüt yapısı rekabetçi piyasada etkin bir stratejik uygulama ve başarı için ön koşuldur (Radomska, 2014: 218). Diğer yandan Bhimani ve Langfield (2007) örgüt yapısının strateji uygulaması üzerindeki etkisini araştırmış ve strateji uygulama sürecinin yapılandırılmış ve formal olması gerektiği sonucuna varmışlardır. Ayrıca strateji geliştirme süreci boyunca finansal bilgilere çok fazla önem verilmesi gerektiğini, uygulama safhasında ise finansal bilgilerin yanı sira finansal olmayan bilgilerin de önemine vurgu yapmışlardır. Markiewicz'in (2011) çalışmasında, süreçlerin ve yapıların stratejilerin başarılı bir şekilde uygulanmasındaki önemini yansıtır ve yaratıcılık, yenilikçilik ve bir organizasyonun süreç olarak algılanmasının stratejilerin uygulanmasında çok önemli olduğunu ifade eder. Slater, Olson ve Hult (2010) altı genel stratejiyi ve bunların uygulanmasını araştırmışlar ve iş başarısı için en etkili perspektifin strateji ve örgütsel yapı arasında uyumu gerektirdiğine karar vermişlerdir.

Bunun için Feurerand Chaharbaghi (1995) önde gelen bilgisayar devi Hewlett-Packard'ın strateji uygulama sürecini incelemiş ve formal örgüt yapısının strateji belirlenmesi ve uygulanmasında geliştirilen bilgi doğrultusunda çalışanların kolaylıkla harekete geçmesi için gerekli olduğunu ileri sürmüşlerdir. 
Son olarak örgütsel strateji ile yapı arasındaki ilişkiyi araştıran birçok çalışma, strateji uygulamada karşılaşılan en önemli zorluklardan biri olarak eylemler arası zayıf koordinasyonu göstermişlerdir. Benzer şekilde Miller, Wilson ve Hickson (2004) rolleri, sorumlulukları ve hesap verebilirliklerini stratejiyle yeniden düzenleyerek zayıf koordinasyonu ekip çalışmasına dönüştürmeyi önerirler.

\section{Temel Uygulama Faktörlerinin İşletme Performansı Üzerine Etkisi}

İşletme performansı firmanın önceden belirlediği ya da sonradan revize ettiği belirli amaçları gerçekleştirmek üzere rekabet stratejilerini ve kaynaklarını uyum içerisinde hareket ettirerek elde ettiği sonuçlar veya uygulama sürecinde sağladığı kazanımlardır (Çalık vd. 2013: 140). Yönetim biliminde araştırmacılar işletmelerin hareketliliğini ve esnekliğini kaybederek ölüm katıllı̆ına düşmemesi, gelişmelerde ve yeniliklerde proaktif roller üstlenebilmesi için performans ölçümünün gerekliliğini vurgulamaktadır. Performans ölçümü kaynak kontrolü ve örgütsel amaçlara ne derece ulaşıldığını belirlemenin yanı sıra (1) örgütün güçlü ve zayıf yönlerinin ve gelecekle ilgili yönelimlerini belirleme (2) yaşanılan başarı ya da başarısızlığın temelindeki süreçleri saptama (3) arzulanan ile gerçekleşen değerler arasındaki farkları ortaya koyma ve yöneticileri, bu farkların azaltılması veya tamamen ortadan kaldırılması yönünde, stratejilere uygun karar almaya yönlendirme gibi konularda değerli bilgileri işletmelere sunmaktadır (Keskin vd, 2016: 115).

İşletme performansı stratejilerin ne kadar iyi formüle edildiğiyle değil aynı zamanda stratejilerin ne kadar iyi uygulandıklarıyla da ilgilidir. Son araştırmalar strateji uygulamanın strateji formülasyonuna göre üstün iş performansının sağlanmasında daha önemli bir gereklilik olduğunu göstermiştir (Flood vd, 2000: 2). Çünkü stratejik plan, çalışanlar ve yönetim tarafindan başarılı bir şekilde uygulamaya aktarılamaz ise bunun maliyeti ve örgüte verdiği zarar strateji oluşturma başarısızlığından daha büyük olacaktır. Ayrıca stratejik yönetim alanında karşılaşılan en önemli sorunlar formülasyondan ziyade uygulamayla alakalıdır ve örgütsel girişimlerin yüksek oranda başarısızlıkla sonuçlanması yeni stratejilerin kötü uygulanması sebebiyledir. Uygulama sadece stratejinin uygulamaya konulması değil tüm kaynakların, çalışanların ve görevlerin yönetilmesidir. Stratejik uygulama bunun yanında işletmelere gelecekteki firsatları belirlemek için yol gösteren dinamik bir süreç olarak ifade edilebilir (Schaap, 2006: 13). Sonuç olarak strateji uygulamanın önündeki temel faktörlerin bilinmesi ve bu faktörlerin örgüt için bir firsat haline dönüştürülmesi ya da en azından zararının minimuma indirilmesi örgütsel performansın artmasına yol açacaktır.

1. İletişim sistemi, Türkiye'deki özel bankalarda stratejinin uygulanmasını nasıl etkiliyor?

2. Liderlik tarzı, Türkiye'deki özel bankalarda stratejinin uygulanmasını nasıl etkiliyor?

3. Örgüt yapısı, Türkiye'deki özel bankalarda stratejinin uygulanmasını nasıl etkiliyor?

4. Örgüt kültürü Türkiye'deki özel bankalarda stratejinin uygulanmasını nasıl etkiliyor?

4. Temel Uygulama Faktörlerinin İşletme Performansına Etkisi Üzerine Bir Araştırma

Türk bankacıllk sektörü, finans kesiminde öncü bir role sahip olmuş ve Türkiye ekonomisinin finansal liberalizasyonuna yönelik yapısal değişikliklere katkıda bulunarak önemli bir gelişme göstermiştir. Nitekim 2008 küresel finansal kriz, 2001 krizinin ardından alınan tedbirlerden kaynaklanan güçlü bir yapı ile karşılanarak, sektörün bu krizden önemli ölçüde etkilenmediğine dikkat çekilmektedir. Yeniden yapılanma ve uluslararası piyasalarla bütünleşme çabalarına paralel olarak; Türk bankacılık sektörü, uluslararası rekabete açık bir sektör halini almıştır. Küresel belirsizlikler karşısında bankaların bu sektörde rekabet güçlerini arttırarak lider konuma gelmeleri çevredeki değişimlere hızla uyum sağlamalarına, bu değişim sürecini içselleştirmelerine ve bir anlamda öğrenen örgüte dönüşmeleriyle mümkündür. Bu tercih gelecek öngörülerinin oluşmasında ve stratejinin planlandığı kadar uygulamasında da dikkat çeker. Çünkü küresel yapı ile entegrasyonu yüksek olan sektör strateji üretimini sadece ulusal ölçekte değil küresel düzeyde de yapmak zorundadır. Bir diğer ifade ile olumlu ve olumsuz açıdan ele alındığında sektörün küresel sermaye ile bütünleşmesi yeni ekonomi açısından yeni stratejik planların gerekliliğini ortaya koymaktadır. Bu da uygulama faktörleri/sürücüleri olan "Liderlik, örgüt kültürü, iletişim ve örgüt yapısı" başlıklarını nasıl kullanıldığını daha önemli bir hale getirmektedir.

\subsection{Araştırmanın Amacı ve Yöntemi}

Çalışmanın amacı, Türkiye'deki bankalarda özellikle iletişim sistemleri, örgüt kültürü, örgüt yapısı ve liderlik tarzının strateji uygulamalarını etkileyip etkilemediğini ve etkiliyorsa bunun sonuçlarının performansa olan katkısını ölçmektir.

$\mathrm{Bu}$ amacı bağlı olarak hipotezler şu şekildedir:

Ho: Türkiye'deki bankacllı sektöründe Illetişim, Liderlik Tarzı, Örgütsel Yapı ve Örgüt Kültürü değişkenleri, Strateji Uygulama Performansı değişkenini açıklamada istatistiksel olarak anlamsizdir.

$\boldsymbol{H}_{1}$ : Türkiye'deki bankactlı sektöründe İletişim, Liderlik Tarzl, Örgütsel Yapı ve Örgüt Kültürü değişkenleri, Strateji Uygulama Performansı değişkenini açıklamada istatistiksel olarak anlamlidir.

$\mathrm{Bu}$ çalışmada, bağımlı ve bağımsız değişkenler ile ilgili birincil veriler, yapılandırılmış bir anket kullanılarak yüklenici firma aracılı̆̆ıyla edinilmiştir. Araştırmada kullanılan ölçek, Waititu (2016)'nun çalışmasından hareketle geliştirilmiş, Türkçeye çevrilip uzman kişilerin görüşleri alınarak düzenlenmiş, denenmiş ve sahaya sürülmüştür. Araştırmaya katılanların bu yargıları değerlendirmesinde anketin ilk haline bağlı kalınmış ve Türkiye'deki uygulamadan farklı olarak "Kesinlikle Kat1lyyorum:1, Katılıyorum:2, Kararsızım:3, Katılmıorum:4, Kesinlikle Katılmıyorum:5" şeklinde beşli likert ölçeğinden yararlanılmıştır.

\subsection{Araştırmanın Örneklemi}

Çalışmanın amacına bağlı olarak, Bankacılık Düzenleme ve Denetleme Kurulu (BDDK) verileri ve sıralamasina göre Türkiye'de yasalarla farklı biçimlerde tanımlanmış ve bankacilık izni olan 52-elli iki- banka ana kütle olup, tam sayılı yöntem kullanılmış ve bunlar içerisinden genel müdürlük, bölge müdürlüğü ve şube müdürlüğü düzeyinde örgütlenmesi olan Özel Mevduat Bankaları, Türkiye'de Kurulu Yabanc1 Mevduat Bankaları, Katılım Bankaları ve Kamu Katılım Bankaları (28 tane) ile çalışma yürütülmüştür. Araştırmada veriler "anket tekniği" ile toplanmıştır. Yapılan saha çalışmasının araştırma evrenini oluşturan 28 (yirmi 
sekiz) bankanın her birinden toplamda 6 (altı) kişiyle yüz yüze ya da telefon yoluyla gerçekleştirilmiş olup bunlar; 2017 yılı Mayıs-Temmuz ayları arasında araştırma firması aracılığg ile toplanmıştır.

Genel müdür veya eşdeğer yetkiye sahip üst düzey yönetici,

Bölge müdürü veya bölge müdür yardımcısı, şube müdürü

olmak üzere toplamda 168 yönetici araştırmadaki örneklemi oluşturmaktadır. Bir anket sonucu (şube düzeyinde) geçersiz kabul edildiğinden 167 anket sonucu analize dâhil edilmiştir. Ankette liderlik tarzı, örgüt kültürü, iletişim sistemi, örgütsel yapı ve strateji uygulama performansını ölçen sorular yer almaktadır. Saha çalışması sonrasında çalışma sonucu elde edilen veriler düzenlenmiş, kodlanmış, daha sonra Sosyal Bilimler için İstatistiksel Paket (SPSS v. 21.0) kullanılarak işlenmek üzere bilgisayara girilmiştir. Katılımcılardan elde edilen verileri analiz etmek için tanımlayıcı istatistiksel metotlar (Frekans, Yüzde, Ortalama, Standart sapma) ve hipotez testleri (Korelasyon Analizi, Regresyon Analizi ve Anova Analizi) kullanılmıştır.

\section{3. Ölçeğin Güvenilirliği}

Tablo 1: Boyutların Güvenilirlik Düzeyleri

\begin{tabular}{|l|c|}
\hline Boyut & Cronbach's Alpha \\
\hline İletişim & 0,562 \\
\hline Liderlik Tarzı & 0,904 \\
\hline Örgütsel Yap1 & 0,895 \\
\hline Örgüt Kültürü & 0,875 \\
\hline Strateji Uygulama Performans1 & 0,949 \\
\hline Genel & 0,952 \\
\hline
\end{tabular}

Anket formunun genel güvenilirliği 0,95 olup her boyut için ayrı ayrı güvenilirlik analizi yapılmıştır. İletişim ölçeği değişkenlerinin genel güvenilirliği 0,56 ; liderlik tarzı ölçeği değişkenlerinin genel güvenilirliği 0,90 ; örgütsel yapı ölçeği değişkenlerinin genel güvenilirliği 0,89 ; örgüt kültürü ölçeği değişkenlerinin genel güvenilirliği 0,87 son olarak strateji uygulama performansı ölçeği değişkenlerinin genel güvenilirliği 0,94 olarak bulunmuştur. Buna göre boyutların genel olarak içsel tutarlılık gösterdikleri söylenebilir.

\section{Araștırmanın Verilerinin Analizleri ve Değerlendirilmesi}

Strateji uygulama performansı ile strateji uygulama sürücüleri arasındaki ilişkiyi göstermek için aşağıdaki çoklu regresyon modeli geliştirilmiştir.

$$
\begin{aligned}
& Y=\beta 0+\beta 1 X 1+\beta 2 X_{2}+\beta 3 X 3+\beta 4 X 4+\varepsilon \\
& \mathrm{Y}=\text { Strateji uygulama performans } 1 \\
& \mathrm{X} 1=\text { Liderlik tarz1 } \\
& \mathrm{X} 2=\text { Örgüt kültürü } \\
& \mathrm{X} 3=\text { İletişim sistemleri } \\
& \mathrm{X} 4=\text { Örgüt yapıs } 1
\end{aligned}
$$

\subsection{Liderlik Tarzı}

Araştırmada, bankalarda uygulanan liderlik tarzı ile strateji uygulama başarısı arasındaki ilişki belirlenmeye çalışılmıştır.

Tablo 2'deki çalışma bulguları, liderliğin banka çalışanları tarafından yol gösterici $(\bar{x}=2.10)$ çözüm bulucu $(\overline{\mathrm{x}}=2,08)$ ve besleyici/destekleyici $(\overline{\mathrm{x}}=2,01)$ bir özellik olarak dikkate alındığını ortaya koymaktadır. Katılımcıların büyük çoğunluğu liderlerin çalışanları ödüllendirdiklerini $(\bar{x}=2.10)$ ve onlara geribildirim sağladıklarını $(\bar{x}=1,99)$ ifade etmektedir. Çalışanları belli bir amaca yönlendirme, bu amaç doğrultusunda motive etme, yeni stratejiler karşısında değişime direnci kırmada üst düzey yönetim önemli gücünü hala elinde tutmaktadır. Liderine inancı olmayan çalışanların örgüt misyon ve vizyonuna şüpheyle yaklaşmalarına daha da ileri gidildiğinde yönetime karşı düşmanca duygu/tavır almalarına yol açacaktır. Dolayısıyla strateji uygulama sürecinin başarısı ve bunun performans üzerine etkisi doğrudan liderin yukarıda bahsettiğimiz etkenleri yönetebilme becerisine bağlı olacağ $(\bar{x}=2,14)$ tüm kademeler tarafından benimsenmiştir.

Tablo 2: Liderlik Tarzı Boyutu Yargılarına Katılım Düzeyleri

\begin{tabular}{|l|r|r|}
\hline \multicolumn{1}{|c|}{ Liderlik Tarzı } & Ortalama & $\begin{array}{c}\text { Std. } \\
\text { Sapma }\end{array}$ \\
\hline Liderler çevrelerinde olan insanlara kendilerini iyi hissettirirler & 1,96 & 0,813 \\
\hline Liderler personele geri bildirim sağlar & 1,99 & 0,788 \\
\hline Liderler diğer çalışanların kendilerini geliştirmelerine yardımcı olur & 2,01 & 0,760 \\
\hline Liderler, personele karmaşık ve zor konularla ilgilenmenin yeni yollarını sunar & 2,08 & 0,764 \\
\hline Liderler, çalışanları başarı gösterdiklerinde ödüllendirir & 2,10 & 0,830 \\
\hline Liderler başkalarının eski sorunlarını yeni yollarla düşünmelerine yardımcı olur & 2,10 & 0,808 \\
\hline Liderler ödüllendirilmek istedikleri takdirde çalışanlara ne yapmaları gerektĭ̌ini söyler & 2,16 & 0,860 \\
\hline Liderler başkalarına birkaç basit kelimeyle neler yapılması gerektiğini söyler & 2,22 & 0,846 \\
\hline Liderler başkalarına ne yapmaları gerektiğini anlamalarına yardımcı olmak için resim, hikaye ve modeller kullanır & 2,28 & 0,883 \\
\hline Çalı̧anlar liderlere tamamen inanırlar & 2,54 & 0,883 \\
\hline Genel Ortalama & 2,14 & \\
\hline $\begin{array}{l}\text { Notlar: (i) n=166, (ii) ölçekte 1=Kesinlikle Katılıyorum ve 5= Kesinlikle Katılmıyorum anlamındadır. } \\
\text { (iii) Friedman çift yönlü Anova testine göre } \chi 2=109,291 \text { p }<0,001 \text { sonuçlar istatistiksel bakımdan anlamlıdır. }\end{array}$ & \\
\hline
\end{tabular}

\section{2. Örgüt Kültürü}

Araştırmada, bankalarda örgüt kültürü ile strateji uygulama başarısı arasındaki ilişkiyi belirlenmeye çalışılmıştır.

Tablo 3 'teki çalışma bulguları, banka yöneticilerinin örgüt kültürü boyutu yargılarına katılım düzeylerini göstermektedir. Buna göre genel olarak örgüt kültürü boyutu yargılarına katılım düzeyleri ortalamanın üstünde yer almaktadır. Örgüt kültürüne bağlı olarak çalışanlara tanınan esnekliğin $(\overline{\mathrm{x}}=2.02)$, formülasyon sürecine onları da dâhil etme geleneğinin strateji uygulamasını olumlu yönde etkilediği sonucuna varılabilir. Çalışanların açıkça tanımlanmış hedeflerinin olması $(\overline{\mathrm{x}}=2,05)$ bu sürece olumlu katk1 sağlayacaktır. Katılımcılar kültürün strateji uygulamalarını etkilediğini kabul etmektedirler $(\overline{\mathrm{x}}=2.11)$. Ayrıca, çalışanların tutumları ile stratejik hedefler güçlü bir uyum içerisinde olduğunda bunun strateji uygulamasını 
geliştirdiği $(\overline{\mathrm{x}}=2,19)$ dolayısıyla performansı iyileştirdiğ $\mathrm{i}$ söylenebilir. Vizyon ve misyon doğrultusunda belirlenmiş olan stratejilerin uygulama tarzı bir başka ifade ile "iş yapma biçimi” örgüt kültürü ile ne denli uyumlu ise, uygulama başarısı, buna bağlı olarak örgüt performansı o denli yüksek olacaktır. Çünkü uygulanmakta olan strateji ile uyumlu bir kültür $(\bar{x}=2,17)$, çalışanların değişime direncini azaltarak stratejinin başarılı bir şekilde uygulanmasına yönelik motivasyonlarını artırır.

Tablo 3: Örgüt Kültürü Boyutu Yargılarına Katılım Düzeyleri

\begin{tabular}{|l|c|c|}
\hline Örgüt Kültürü & Ortalama & Std. Sapma \\
\hline Bankaların çalışma ortamında, yeni fikirlere hoşgörü vardır ve bu strateji uygulamasını geliştirir & 2,02 & 0,825 \\
\hline Banka misyon ve değerlerine her zaman bağlı kalır bu da etkin bir strateji uygulamasına yardımcı olur. & 2,05 & 0,849 \\
\hline Bireylerin ve ekiplerin, işin amaç ve misyonuyla ilgili açıça tanımlanmış hedefleri vardır & 2,05 & 0,801 \\
\hline Bankaların değer tablolarının veya değer/kültürlerinin anlaşılması strateji uygulamasını kolaylaştırır & 2,11 & 0,832 \\
\hline Örgüt külttürü strateji uygulamasını etkiler & 2,11 & 0,857 \\
\hline Stratejik girişimlerin uygulanmasını desteklemek ve bunu sürdürmek için motivasyon yüksektir & 2,13 & 0,815 \\
\hline İnsanlar değişiklikler karşısında esnek ve uyarlanabilirler & 2,17 & 0,806 \\
\hline Çalışanların tutumları ile stratejik hedefleri güçlü bir uyum içindedir ve bu strateji uygulamasını geliştirir & 2,19 & 0,776 \\
\hline Banka örgüt genelinde çalışanlar arasında açık vizyon, misyon ve değerlere sahiptir & 2,26 \\
\hline Çalışanlar operasyonel hedeflere ulaşmak için bazen şirket politikalarından/ilkelerinden ödün verirler & 0,950 \\
\hline Genel Ortalama & 2,68 & 1,115 \\
\hline $\begin{array}{l}\text { Notlar: (i) } n=167, \text { (ii) ölçekte 1=Kesinlikle Katıllıyorum ve 5= Kesinlikle Katılmıyorum anlamındadır. } \\
\text { (iii) Friedman çift yönlü Anova testine göre } \chi 2=69,046 \text { p }<0,001 \text { sonuçlar istatistiksel bakımdan anlamlıdır. }\end{array}$ & 2,17 & \\
\hline
\end{tabular}

\section{3. İletişim Sistemleri}

Araştırmada, bankalarda iletişim sistemi ile strateji uygulama başarısı arasındaki ilişki belirlenmeye çalışılmıştır.

Tablo 4'deki çalışma bulguları, çalışanların iletişim noktasında özellikle etkileşime vurgu yaptıklarını göstermektedir. Katılımcılar karşılıklı ilişkinin iletişimi güçlendirdiği konusunda hemfikirdir $(\bar{x}=1,64)$. Örgütteki iletişim sisteminin strateji uygulamasını etkilediği büyük ölçüde destek görmektedir $(\overline{\mathrm{x}}=1,93)$. Strateji uygulama süreci boyunca etkin iletişimin, örgüt performansını da geliştirdiğini ortaya koymaktadır. Değişimin kabul edilmesi ve uygulanması sırasında direnci azaltabilmenin yolu da yine iletişimden geçmektedir. Katılımcıların çoğunluğu, örgütteki iletişimin, strateji uygulamasını etkilediğine ve iletişimdeki bazı sorunların strateji uygulamasında başarısızlığa yol açtığını kabul etmişlerdir. Ankete katılanların tümüne bakıldığında $(\bar{x}=2,23)$ her seviyedeki çalışan uygulama için iletişimin önemini vurgulamışlardır. $\mathrm{Bu}$ durum Hitt ve diğerleri (2007) tarafindan desteklenmektedir. Yazılı raporlar açık ve anlaşılırdır yargısı da büyük ölçüde desteklenmektedir $(\bar{x}=1,97)$. Örgüt üyeleri arasındaki resmi ve gayri resmi iletişim gidilecek yön konusunda fikir birliği oluşturma ve belirlenen stratejilerin doğru bir şekilde örgüt geneline aktarılması (Hambrick ve Cannella, 1989) ve çalışanlar tarafından da doğru bir şekilde anlaşılmasını sağladığından strateji uygulama sürecinde önemli bir faktördür.

Tablo 4: İletişim Boyutu Yargılarına Katılım Düzeyleri

\begin{tabular}{|c|c|c|}
\hline İletişim & Ortalama & Std. Sapma \\
\hline Karşılıklı ilişki iletişimi güçlendirir & 1,64 & 0,679 \\
\hline Kullanılan iletișim sistemlerinin strateji uygulamasını etkilediğini düşünüyorum & 1,93 & 0,697 \\
\hline Yazılı direktifler / raporlar açık ve anlașlırdır & 1,97 & 0,790 \\
\hline Stratejik değişim uygulaması etkili bir şekilde iletilir & 1,99 & 0,701 \\
\hline İletişim uygulamaları acil durumlara uyarlanabilir & 2,08 & 0,755 \\
\hline $\begin{array}{l}\text { Değişikliklerin / geri bildirimlerin etkisinin değerlendirilmesinde bankaların etkinliği iyi yapılandırılmış iletişim } \\
\text { sistemine bağlıdır. }\end{array}$ & 2,13 & 0,666 \\
\hline $\begin{array}{l}\text { Değişimin kabul edilmesi ve uygulanmasına yönelik isteklilik, kısmen kurulan iletişim sisteminin özenle/ayrıntılı } \\
\text { olarak hazırlanmasına bağlıdır. }\end{array}$ & 2,14 & 0,582 \\
\hline İç iletișimdeki bazı sorunlar, değișim uygulamasında bașarısızlığa neden olmuștur & 2,51 & 1,066 \\
\hline Dedikodu organizasyonumuzda aktiftir & 2,92 & 1,188 \\
\hline Astlar, yukarıdan aşağıya iletişime tepki gösteriyorlar & 2,95 & 1,078 \\
\hline Genel Ortalama & 2,23 & \\
\hline
\end{tabular}

\section{4. Örgüt Yapısı}

Çalışma, bankalarda örgüt yapıları ile strateji uygulama başarısı arasındaki ilişkiyi belirlemeye çalışmıştır.

Tablo 5'teki çalışma bulguları, banka yöneticilerinin örgütsel yap1 boyutu yargılarına katılım düzeylerini göstermektedir. Buna göre genel olarak örgütsel yapı boyutu yargılarına katılım düzeyleri ortalamanın üzerinde yer almaktadır ( $\bar{x}=2,12)$. Katılımcılar, bankanın işlevsel ve süreç odaklı bir yapıya sahip olduğunu onaylamışlar ve örgüt yapısının strateji uygulamasını etkilediği yargısını büyük ölçüde desteklemişlerdir. Strateji uygulama süreci boyunca doğru bir örgüt yapısı, başarılı bir uygulamaya dolayısıyla örgütsel performansın iyileştirilmesinde büyük ölçüde katkıda bulunur. Banka yöneticileri örgüt yapısının gerek finansal $(\overline{\mathrm{x}}=1,98)$ gerek insan kaynakları $(\overline{\mathrm{x}}=2,07)$ açısından olumlu bir seyir izlediğini, yönetimin her kademesinde karar vermeyi kolaylaştırdığını $(\overline{\mathrm{x}}=2,53)$ ve bu nedenle strateji uygulama sürecinde karşılaş1labilecek sorunlara karşı duyarlılığın arttığını ifade etmişlerdir. Sonuçlar ayrıca, örgüt yapısının, yönetim ve işlev alanlarının farklı seviyeleri arasında bilgi, koordinasyon ve işbirliğinin serbest dolaşımını kolaylaştırdığını ve bu, kuruluş birimleri arasında çalışma verimliliğini artırdığını ortaya koymuştur. Katılımcılar önemli ölçüde örgüt yapısının strateji uygulamasını etkilediğini $(\overline{\mathrm{x}}=2,03)$ ifade etmişlerdir. Bu Hrebiniak'ın 
(2005) örgütsel yapının, stratejinin başarıyla uygulanması için önemli bir unsur olduğu ifadesiyle paralellik göstermektedir. Banka yapısı strateji uygulanması için kritik olan örgütsel esnekliği artırır yargısı katılımcılar tarafından desteklenmektedir ( $\bar{x}=2,32)$. Mekanik ve katı bir yaklaşımın, stratejinin oluşturulması ve uygulanmasında sorunlara yol açacağını söylenebilir. Stratejik amaç ve misyonla uyumlu ve gerek iç gerekse dış paydaş ihtiyaçlarına etkili şekilde cevap veren bir örgüt yapısının geliştirilmesi, başarılı bir stratejik uygulama için elzemdir. Bürokratik örgüt yapıları, tüm bölümlerde stratejinin uygulanmasını yavaşlatan bir etkiye sahiptir.

Tablo 5: Örgütsel Yapı Boyutu Yargılarına Katılım Düzeyleri

\begin{tabular}{|c|c|c|}
\hline Örgütsel Yapı & Ortalama & Std. Sapma \\
\hline Banka fonksiyonel ve süreç odaklı bir yapıya sahiptir & 1,91 & 0,870 \\
\hline Banka stratejileri uygulamak için gerekli finansal kapasiteye sahiptir & 1,98 & 0,868 \\
\hline Örgüt yapısı strateji uygulamasını etkiler & 2,03 & 0,779 \\
\hline Bankanın mevcut yapısı, stratejik girişimlerin uygulanmasını desteklemek için uygundur. & 2,04 & 0,860 \\
\hline Yeni stratejik yönü yönetmek ve uygulamak için İK kapasitesi yeterlidir & 2,07 & 0,749 \\
\hline Bankanın verimliliğini artıran çok sayıda uzman fonksiyonu vardır & 2,07 & 0,879 \\
\hline Stratejinin uygulanmasında kurumsal etkinlik yardımci roldedir & 2,15 & 0,804 \\
\hline Çalıșanlar neyi niçin yaptıkları yani amaçları ve görevleriyle ilgili yeterli bilgiye sahiptirler & 2,19 & 0,804 \\
\hline Banka yapısı strateji uygulanması için kritik olan örgütsel esnekliği artırır & 2,32 & 0,815 \\
\hline Örgüt yapısı strateji uygulanması için kritik olan bilginin serbest akışını destekler & 2,53 & 0,805 \\
\hline Genel Ortalama & 2,12 & \\
\hline
\end{tabular}

\subsection{Strateji Uygulama Performansı}

Çalışma, strateji uygulama performansını önemli etkenlere, yani örgüt kültürü, organizasyon yapısı, liderlik tarzı ve iletişim sistemleri temelinde değerlendirmeye çalışmıştır.

Tablo 6'daki çalışma bulguları araştırmaya katılan banka yöneticilerinin strateji uygulama performansı boyutu yargılarına katılım düzeylerini göstermektedir. Buna göre genel olarak strateji uygulama performansı boyutu yargılarına katılım düzeyleri ortalamanın üstünde yer almaktadır ( $\bar{x}=$ : 2,22). Katılımcılar uygulanan iyi stratejilerin son beş yılda faaliyetlerini (2,08), kârlılık seviyesini $(\bar{x}=2,10)$, satış hacmini $(\bar{x}=2,18)$, süreç verimliliğini $(\bar{x}=2,13)$ artırdığını ifade etmişlerdir. Son beş yılda yaşanan müşteri tabanındaki artış $(2,22)$, ilgili süre içerisinde çalışan sayısı $(\bar{x}=2,49)$ ve hisse değerinde de artışa neden olmuştur $(\bar{x}=2,24)$. Banka yöneticileri genel olarak varlık getirisinden $(\overline{\mathrm{x}}=2,28)$ ve özkaynak getirisinden memnundurlar $(\overline{\mathrm{x}}=2,29)$. Son olarak müşterilerin aldığı ürünler önemli ölçüde artmıştır yargısı $(\overline{\mathrm{x}}=2,23)$ katılımcılar tarafindan desteklenmektedir.

Tablo 6: Strateji Uygulama Performansı Boyutu Yargılarına Katılım Düzeyleri

\begin{tabular}{|c|c|c|}
\hline Strateji Uygulama Performansı & Ortalama & $\begin{array}{r}\text { Std. } \\
\text { Sapma }\end{array}$ \\
\hline Banka, son 5 y1lda faaliyetlerini genişletti & 2,08 & 0,994 \\
\hline Uygulanan iyi stratejiler, son beş y1l boyunca karlılık seviyemizi yükseltti. & 2,10 & 0,916 \\
\hline İç iş süreçlerinde verimlilik arttı & 2,13 & 0,886 \\
\hline Uygulanan iyi stratejiler, son beş yılda satış hacmini artırdı. & 2,18 & 0,940 \\
\hline Müşteri tabanında son 5 yılda artış oldu & 2,22 & 1,008 \\
\hline Müşterilerin aldığı ürünler önemli ölçüde artmıştır & 2,23 & 0,988 \\
\hline Hisse değerimiz son 5 y1lda arttı & 2,24 & 0,933 \\
\hline Banka yönetimi varlığın getirisinden memnun & 2,28 & 0,950 \\
\hline Banka yönetimi özkaynak kârlılığından memnun & 2,29 & 0,971 \\
\hline Son beş yılda çalışan sayısı arttı & 2,49 & 1,086 \\
\hline Genel Ortalama & 2,224 & \\
\hline
\end{tabular}

\subsection{Değişkenler Arası Korelasyon Analizi}

Strateji uygulama performansının sürüler ile olan ilişkisi irdelendiğinde, elde edilen veriler uygulamacıları hangi sürücüyü nasıl kullanması gerektiğini ortaya koymaktadır.

Tablo 7 Pearson Korelasyon değerlerini vermektedir. Bu değerler incelendiğinde;

- Illetişim değişkeni ile Strateji Uygulama Performansı değişkeni arasında 0.01 güvenilirlik düzeyinde düşük ve anlamlı bir ilişkinin varlığı tespit edilmiştir (Pearson Korelasyon: 0,148).
- Liderlik Tarzı değişkeni ile Strateji Uygulama Performansı değişkeni arasında 0.01 güvenilirlik değerine göre orta düzeyli ve anlamlı bir ilişkinin varlığı tespit edilmiştir (Pearson Korelasyon: 0,515).

- Örgütsel Yapı değişkeni ile Strateji Uygulama Performansı değişkeni arasında 0.01 güvenilirlik değerine göre orta düzeyli ve anlamlı bir ilişkinin varlığı tespit edilmiştir (Pearson Korelasyon: 0,641).

- Örgütsel Kültür değişkeni ile Strateji Uygulama Performansı değişkeni arasında 0.01 güvenilirlik değerine göre orta düzeyli ve anlamlı bir ilişkinin varlığı tespit edilmiştir (Pearson Korelasyon: 0,630). 
M.A. Arıcıŏ̆lu, Ş. Gökce, M.N. Salur / KMÜ Sosyal ve Ekonomik Araştırmalar Dergisi 19 (33): 103-113, 2017

Tablo 7: Korelasyon Analizi (Pearson)

\begin{tabular}{|c|c|c|c|c|c|c|}
\hline \multicolumn{7}{|c|}{ Korelasyon Analizi } \\
\hline & & İletişim & Liderlik Tarzı & Örgütsel Yapı & $\begin{array}{l}\text { Örgütsel } \\
\text { Kültürr }\end{array}$ & $\begin{array}{l}\text { Strateji Uygulama } \\
\text { Performansi }\end{array}$ \\
\hline \multirow[t]{2}{*}{ İletişim } & PearsonKo & 1 & $0,353 * *$ & $0,382 * *$ & $0,247 * *$ & 0,148 \\
\hline & $\begin{array}{l}\text { Çift Kuyruk } \\
\text { Anlamlılık } \\
\text { Değeri }\end{array}$ & & 0,00 & 0,00 & 0,00 & 0,06 \\
\hline \multirow[t]{2}{*}{ Liderlik Tarzı } & PearsonKo & $0,353 * *$ & 1 & $0,715^{* * *}$ & $0,655^{* * *}$ & $0,515^{* * *}$ \\
\hline & $\begin{array}{l}\text { Çift Kuyruk } \\
\text { Anlamlılık } \\
\text { Değeri }\end{array}$ & 0,00 & & 0,00 & 0,00 & 0,00 \\
\hline \multirow[t]{2}{*}{ Örgütsel Yapı } & PearsonKo & $0,382 * *$ & $0,715^{* * *}$ & 1 & $0,780^{* * *}$ & $0,641^{* * *}$ \\
\hline & $\begin{array}{l}\text { Çift Kuyruk } \\
\text { Anlamlılık } \\
\text { Değeri }\end{array}$ & 0,00 & 0,00 & & 0,00 & 0,00 \\
\hline \multirow[t]{2}{*}{ Örgütsel Kültür } & PearsonKo & $0,247 * *$ & $0,655 * *$ & $0,780^{* * *}$ & 1 & $0,630 * *$ \\
\hline & $\begin{array}{l}\text { Çift Kuyruk } \\
\text { Anlamlılık } \\
\text { Değeri } \\
\end{array}$ & 0,00 & 0,00 & 0,00 & & 0,00 \\
\hline \multirow[t]{2}{*}{ Strateji Uygulama Performansı } & PearsonKo & 0,148 & $0,515^{* *}$ & $0,641 * *$ & $0,630^{* * *}$ & 1 \\
\hline & $\begin{array}{l}\text { Çift Kuyruk } \\
\text { Anlamlılık } \\
\text { Değeri }\end{array}$ & 0,06 & 0,00 & 0,00 & 0,00 & 0,00 \\
\hline
\end{tabular}

\subsection{Tüm Değişkenler için Model Geçerliliği}

Ho: Türk bankacılık sektöründe İletişim, Liderlik Tarzl, Örgütsel Yapı ve Örgüt Kültürü değişkenleri, Strateji Uygulama Performansı değişkenini açıklamada istatistiksel olarak anlamsizdır.

$\boldsymbol{H}_{1}:$ Türk bankacıllk sektöründe İletişim, Liderlik Tarzl, Örgütsel Yapı ve Örgüt Kültürü değişkenleri, Strateji Uygulama Performansı değişkenini açıklamada istatistiksel olarak anlamlıdır.
Tablo 8'deki ANOVA tablosu incelendiğinde $\mathrm{F}$ değeri 34,936 ve $\mathrm{p}$ değeri 0,00 olduğundan $\mathrm{H}_{0}$ hipotezinin reddine karar verilir. Buna göre oluşturulan regresyon modeli genelde istatistiksel olarak anlamlidir. Yani Strateji Uygulama Performansı değişkenini İletişim, Liderlik Tarzı, Örgütsel Yapı ve Örgüt Kültürü değişkenlerinden en az biri ile tahmin etmek istatistiksel olarak mümkündür.

Tablo 8: ANOVA Tablosu

\begin{tabular}{|c|c|c|c|c|c|}
\hline Model & $\begin{array}{c}\text { Kareler } \\
\text { Toplamı }\end{array}$ & $\begin{array}{c}\text { Serbestlik Derecesi } \\
\text { (df) }\end{array}$ & $\begin{array}{c}\text { Kareler } \\
\text { Ortalaması }\end{array}$ & F & P \\
\hline Regresyon & 49,447 & 4 & 12,362 & \multirow{2}{*}{34,9} & 0,00 \\
\cline { 1 - 3 } Artık & 56,967 & 161 & 0,354 & 36 & 0 \\
\hline Toplam & 106,414 & 165 & & \\
\cline { 1 - 3 } a: Bağımsız Değişkenler: (Sabit), İletişim, Liderlik Tarzı, Örgütsel Yapı ve Örgüt Külttürü \\
b: Bağımlı Değişken: Strateji Uygulama Performansı
\end{tabular}

Tablo 9: Regresyon Katsayıları

\begin{tabular}{|c|c|c|c|c|c|}
\hline \multirow[t]{2}{*}{ Model } & \multicolumn{2}{|c|}{$\begin{array}{c}\text { Standardize Edilmemiş } \\
\text { Katsayılar }\end{array}$} & \multirow{2}{*}{$\begin{array}{r}\begin{array}{r}\text { Standart } \\
\text { Katsayılar }\end{array} \\
\text { Beta }\end{array}$} & \multirow[t]{2}{*}{$\mathbf{t}$} & \multirow[t]{2}{*}{$\mathbf{P}$} \\
\hline & B & Std. Hata & & & \\
\hline (Sabit) & 0,486 & 0,296 & & 1,643 & 0,102 \\
\hline İletişim & $-0,216$ & 0,134 & $-0,102$ & $-1,613$ & 0,109 \\
\hline Liderlik Tarzı & 0,092 & 0,114 & 0,070 & 0,813 & 0,417 \\
\hline Örgütsel Yapı & 0,533 & 0,142 & 0,393 & 3,744 & 0,000 \\
\hline Örgüit Kültürü & 0,409 & 0,128 & 0,304 & 3,187 & 0,002 \\
\hline
\end{tabular}

Tablo 9'daki regresyon katsayıları tablosu incelendiğinde iletişim ve liderlik tarzı değişkenlerinin $\mathrm{p}$ değerleri 0,05 'den büyük olduğu için istatistiksel olarak anlamlı değillerdir. Bunun dışındaki örgütsel yapı ve örgüt kültürü değişkenleri $p$ değerleri 0,05 'den küçük olduğu için bankacılık sektöründe strateji uygulama performansı değişkenini açıklamada istatistiksel olarak anlamlıdır.

\begin{tabular}{|l|}
\hline Regresyon Tahmin Modeli \\
\hline Strateji Uygulama Performansı = 0,486 - 0,216 \\
Iletişim + 0,092 Liderlik Tarzı + 0,533 Örgütsel Yapı + \\
0,409 Örgüt Kültürü \\
\hline
\end{tabular}

Tablo 10: Regresyon Model Özeti

\begin{tabular}{|c|c|c|c|}
\hline $\mathbf{R}$ & ${ }_{2} \mathbf{R}$ & $\begin{array}{l}\text { Düzeltilm } \\
\text { iş } R^{2}\end{array}$ & $\begin{array}{l}\text { Tahminin Std. } \\
\text { Hatası }\end{array}$ \\
\hline $\begin{array}{r}0 \\
682\end{array}$ & $\begin{array}{r}0 \\
4655\end{array}$ & 0,451 & 0,59484 \\
\hline
\end{tabular}

Yapılan regresyon analizi sonucunda İetişim, Liderlik Tarzl, Örgütsel Yapı ve Örgüt Kültürü değişkenlerinin, Strateji Uygulama Performansı değişkenini açıklama oranı yaklaşık olarak \%47 olarak bulunmuştur.

\section{Sonuç ve Öneriler}

Stratejik yönetim literatüründe strateji uygulaması stratejik planlamadan daha az dikkat çekmektedir. Planlamanın gölgesinde kalan strateji uygulamasının niteliği 
hakkında nispeten az şey bilinmektedir. Bu konuya dair yapılan araştırmalarda genelde strateji uygulamanın önündeki engellerin araştırılmasına dairdir. $\mathrm{Bu}$ yaklaşım, genellikle başarılı bir uygulama ile ilgili sorunlara odaklanmayı, potansiyel engelleri belirlemeyi ve bunları aşmak için çözüm önerileri geliştirmeyi amaçladığından strateji uygulamanın üstün performansa nasıl katkıda bulunduğu konusunda çok az çalışma yapılmıştır. Stratejik yönetim anlayışındaki bu önemli boşluğun giderilmesi için, bu çalışma belirli temel faktörlerin (liderlik, kültür, iletişim, yap1) strateji uygulamasını ne yönde etkilediği ve bu yolla örgüt performansına katkısını ortaya koymaya çalışmıştır. Araştırma bulguları ve araştırma soruları yanıtlarından, çalışma ile ilgili bazı sonuçlar ortaya konmuştur.

$\mathrm{Bu}$ çalışmada, örgüt kültürünün strateji uygulama performansıyla pozitif ve anlamlı bir ilişkisi olduğu açıtır. Araştırma bulgularına göre, çalışma örgütsel kültürün, paylaşılan inanç ve değerler yoluyla bankalardaki strateji uygulamasını etkilediği sonucunu ortaya koymuştur. Öte yandan, paylaşılan değerler ve normlar çalışanlar arasında etkileşim ve koordinasyonu kolaylaştırarak etkin bir strateji uygulamasına da katkıda bulunmaktadır. Örgüt kültürü ile stratejik hedefler güçlü bir uyum içerisinde olduğunda bunun strateji uygulamasını geliştirdiği dolayısıyla performansı iyileştirdiği söylenebilir. Yani örgüt, stratejisini zamanla kucaklayan bir örgüt kültürünü desteklemelidir. Üst yönetim uygulamaları aracılığıyla sürekli şekillendiği ileri sürülen örgüt kültürü yöneticilerin liderlik tarzını, strateji uygulama anlayışını, uygulama sırasında karşılaşılan zorlukların ve engellerin tanımlanmasını, yöneticilerin karar vermelerini ve hakim değerleri, inançları ve normları etkiler. Çalışma örgüt kültürünün tanınan esneklik, katılımcı bir anlayış ve ödüller aracılığıyla çalışanlara gösterildiğini ve çalışanların ilerlemeye devam etmesi ve stratejinin etkin bir şekilde uygulanması için kendi amaç ve hedeflerini örgütsel hedeflerin uygulanmasına yönlendirdiğini ortaya koymuştur. $\mathrm{Bu}$ bütünleşme doğrudan strateji uygulama performansını olumlu yönde etkileyecektir.

İletişim, strateji uygulama sürecinin kilit faktörüdür. Strateji, uygulanmadan önce tüm çalışanlara yazılı açık ve net bir şekilde iletilmelidir. Yönetici strateji uygulama sürecini düzenli olarak değerlendirmeli ve düzeltici önlemlerin zamanında alınması için geri bildirimde bulunmalıdır. Tüm bu eylemlerin başarı düzeyi örgüt içerisindeki iletişimin kalitesine bağlı olacaktır. Bu çalışmada iletişim sistemi ile strateji uygulama performansı arasında pozitif ve anlamlı bir ilişkinin varlığı tespit edilmiştir. Araştırma bulgularına göre bankacılık sektöründe çalışanlar iletişimin strateji uygulama sürecini önemli ölçüde etkilediğini düşünmektedirler. Yine çoğu banka çalışanı, üst yönetimin stratejik değişim uygulamalarını yazılı ve açık şekilde ilettiklerini belirtmiştir. Ayrıca, çalışma yöneticilerin/liderlerin strateji ilerleme değerlemesinden sonra çalışanlara geri bildirimlerin sağlamasında iletişimin önemini ortaya koymuştur. Banka yöneticileri strateji uygulamada yaşanan olumsuzlukların kötü iletişim sürecinin bir sonucu olduğunu belirtmişılerdir. Bir başka sonuç ise, iletişimin örgüt içerisindeki değişimin kabul edilmesi ve uygulanmasına yönelik isteği artıracağı noktasındadır. Bu sonuç bankalarda ekipler arasında yüksek motivasyona sahip çalışanlara ve bankalar tarafından arzulanan örgüt hedeflerine ulaşılmasına yol açacaktır. Araştırma bulgularına dayanarak, iletişimin bankacılık sektöründe stratejinin başarılı bir şekilde uygulanması için önem taşıdığını ve bu iletişimin yöneticilere planlama, örgütleme, motive etme ve denetleme gibi stratejik yönetimin temel işlevlerini yerine getirmesinde yardımcı olduğunu söyleyebiliriz. Sonuç olarak etkin bir iletişimin stratejinin örgüt üyeleri arasında yorumlama ve anlayış bakımdan oluşabilecek farklılıkları ortadan kaldırarak, yön birliği sağlaması uygulamada oluşabilecek sorunların yine aynı yolla en kısa sürede çözüme kavuşturulması bu sürecin sağlıklı bir şekilde ilerlemesine yol açarak strateji uygulama performansını artıracaktır.

Liderlik veya üst yönetimin stratejik yöne bağlılı̆̆ önemlidir ve liderlerin strateji uygulama fikrinin etkili olmasını sağlamak için çalışanlarını ikna etmeye (ilham vermeye ve motive etmeye) özen göstermelidir. Bu çalışmada liderlik tarzı ile strateji uygulama performansı arasında pozitif ve anlamlı bir ilişkinin varlığı tespit edilmiştir. Araştırma bulgularına dayanarak, bankacılık sektöründe liderliğin çalışanlar tarafından yol gösterici, yeni çözümler üreten ve çalışanlarını sürekli destekleyerek onların gelişimine yardımcı olan bir özellik olarak görüldüğü ifade edilebilir. Lider, çalışanların kendilerini iyi hissetmelerini sağlamalı ve strateji uygulama sürecine nasıl katkı sağlayacakları noktasında onlara yol göstermelidir. Ayrıca araştırma çalışanların bu süreçte başarı gösterdikleri takdirde liderler tarafından ödüllendirildiğini ortaya koymuştur. Liderler, örgüt hedeflerine ulaşmak için neler/nasıl yapılması gerektiği konusunda çalışanlarının yetenek ve becerilerini yakından takip etmeli, strateji uygulama sürecini ileriye taşıyabilecek en iyi insanları ve ekipleri seçebilir olmalıdır. Sonuç olarak bankalarda etkin bir strateji uygulama performansının ortaya konmasında yöneticilerden yukarıda saydığımız özelliklere sahip daha fazla liderlik rolü göstermeleri beklenmektedir.

$\mathrm{Bu}$ çalışmada örgütsel yapı ile strateji uygulama performansı arasında pozitif ve anlamlı bir ilişkinin varlığı tespit edilmiştir. Araştırma bulgularından elde edilen ilk sonuç, örgüt yapısının strateji uygulanmasını etkilediğidir. Özellikle, demokratik yönetim tarzının stratejik planların uygulanması üzerinde olumlu etkisi vardır. Çalışma aynı zamanda karar vermeyi, bilgi akışını serbest bırakan, yönetim ve fonksiyonel alanların farklı seviyeleri arasında koordinasyonu ve işbirliğini kolaylaştıran bir örgüt yapısının strateji uygulamasının başarı düzeyini artıracağını ortaya koyuyor. Bir diğer sonuç, yönetim kurulu, fonksiyonel ya da işletme yöneticileri de dahil olmak üzere her düzeydeki insan kaynağının stratejik planların etkili bir şekilde uygulanmasını önemli ölçüde etkilediğidir. Bankaların önemli unsurlarını yönlendiren örgüt yapısı; üst yönetimin çevresel değişime tepki vermesini kolaylaştırmak suretiyle stratejilerin uygulanmasını etkiler ve bu örgütün strateji uygulamasının önündeki engellerle baş etmesine yardımcı olur. Uzman fonksiyonlar yardımıyla stratejik girişimlerin yönü doğrultusunda sağlanan verimlilik ve etkinlik artışı strateji uygulama performansını da olumlu yönde etkileyecektir.

\section{Kaynaklar}

Ahmadi, A. A. Salamzadeh, Y. Daraei, M. ve Akbari, J. (2012) "Relationship between Organizational Culture and Strategy Implementation: Typologies and Dimensions" Global Business and Management Research: An International Journal, 4 (3): 280-286. 
Alashloo, R. F. Castka, P. ve Sharp, J.M. (2005) "Towards understanding the impeders of strategy implementation in higher education (HE)" Quality Assurance in Education; 13 (2): 52-67.

Alexander, L. (1985) "Successfully Implementing Strategic Decision" Long Range Planning, 18 (3): 91-97.

Beer, M. ve Eisenstat, R. (2000) "The Silent Killers of Strategy Implementation and Learning" Sloan Management Review, 41 (4): 29-40.

Bhimani, A. ve Langfield-S, K. (2007) "Structure, Formality and the Importance of Financial and Non-financial Information in Strategy Development and Implementation" Management Accounting Research, 18(1): 3- 31.

Boomer, G. (2007) IT Strategies and Tactics, Accounting Today, August 20.

Brenes, E. Mena, M. ve Molina, G. (2008) "Key success factors for strategy implementation in Latin America" Journal of Business Research, 61: 595.

Cobbold, I. ve Lawrie, G. (2002) The development of the Balanced Scorecard as a strategic management tool, 2GC Active Management.

Cater, T. ve Pucko, D. (2010) "Factors of Effective Strategy Implementation: Empirical Evidence from Slovenian Business Practice" Journalfor East European Management Studies, 15(3): 207-236.

Chandler, A.D. (1962) "Strategy and Structure: Chapters in the History of the American Industrial Enterprise" Cambridge, MA: MIT Press.

Çalık, M. Altunışık, R. ve Sütütemiz, N. (2013) "Bütünleşik pazarlama iletişimi, marka performansı ve pazar performans ilişkisinin incelenmesi” Uluslararası Yönetim İktisat ve İşletme Dergisi, 9(19): 138-161.

David, F. R. (2007) Strategic Management: Concepts and Cases,NY: Prentice Hall.

Feurer, R. ve Chaharbaghi, K. (1995) "Strategy development: past, present and future", Management Decision, 33(6): 11-21

Flood, C. Margaret, M. ve Heffernan, P. (2000) "An exploration of the relationships between the adoption of managerial competencies, organisational characteristics, human resources ophistication and performance in Irish organisations", Journal of European Industrial Training, 24 (2/3/4): 128-136,

Forman, J. ve Argenti, P.A. (2005) "How Corporate Communication Influences Strategy Implementation, Reputation and the Corporate Brand: An Exploratory Qualitative Study" Corporate Reputation Review, 8: 245-264.

Foster, J. ve Browne, M. (1996) Principles of Strategic Management. Macmillan Education, South Yarra, 47.

Freedman, M. (2003) "The Genius is in the Implementation" Journal of Business Strategy, 24 (2): 26-31.

Getz, G. ve Lee, J. (2011) "Why Your Strategy Isn'tWorking" Business Strategy Series, 12(6): 303-307.

Hambrick, D. C. ve Cannella, A. A. (1989) "Strategy Implementation as Substance and Selling" Academy Management Perspective, 3(4): 278-285.

Harrington, R.J. (2006) "The Moderating Effects of Size, Manager Tactics and Involvement on Strategy Implementation in Food Service ${ }^{e c}$ Hospitality Management, 25: 373-397.

Hitt, M.A. Hoskisson, R.E. ve Ireland, R.D. (2007) Management of Strategy (International Student Edition). China: Thomson SouthWestern

Hrebiniak, L. G. (2005) Making Strategy Work: Leading Effective Execution and Change Wharton School Publishing, 3rd printing, July, New Jersey.

Joubert, C. (1988) "Strategy In The Public Sector" Public Money \& Management, Autumn:17-19.
Kamanda, C. (2006) "Factors influencing the regional growth strategy at KCB" Unpublished MBA Project, School of Business, University of Nairobi.

Keskin, H, Zehir, S. ve Ayar, H. (2016) "Pazar Yönelimi ve Firma Performansı İlişkisi: Farklılaştırma Stratejisinin Aracı Rolü” Doğuş Üniversitesi Dergisi, 17 (1): 111-127.

Lares-Mankki, L. (2014) "Strategy Implementation Bottlenecks: Identification, Analysis and Removal" Lappeenranta University of Technology, Lappeenranta.

Lepsinger, R. (2006) "Surveying the gap: Nearlyhalf of all leader see a disconnect between strategy and execution" Business Credit, October, 56-57.

Markiewicz, P. (2011) "Change Management in the Strategy Implementation Process" Intelektine Ekonomika, 5(2): 257-267.

Mezias, J. M. ve Starbuck, W.H. (2003) "Studying the Accuracy of Managers Perceptions: A Research Odyssey", British Journal of Management, (14): 3-17.

Miller, S. (1997) "Implementing Strategic Decisions: Four Key Success Factors” Organization Study, 18(4): 577-602.

Noble, C.H. (1999) "The Eclectic Roots of Strategy Implementation Research" Journal of Business Research, (45): 119134.

Okumuş, F. (2003) "A Framework to Implement Strategies in Organizations" Management Decision, 41 (9): 871-882.

O'Reilly, C.A. Caldwell, D. F. Chatman, J.A. Lapiz, M. ve Self, W. (2010) "How Leadership Matters: The Effects of Leaders' Alignment on Strategy Implementation" Leadership Quarterly, 21(1): 104-113.

Otiso, H. N. (2008) Strategic change management practices: The case of Africa Merchant assurance company. Unpublished MBA Project.

Pearce, J. A.,ve RobinsonJr., R. B. (2003). Strategic Management: Formulation, Implementation and Control. 8th Edition, Business Week, Mc Graw-HillCompaniesInc., New York, N.Y.

Radomska, J. (2014) "Model of Successful Strategy Execution: Revising The Concept" Problems of Management in The 21. Century 9(3): 213-222.

Rumelt, R. P. (2011) “The Perils of Bad Strategy" Mc Kinsey Quarterly, (1): 30-39.

Sarvan, F. ve diğerleri (2003) "On Stratejik Yönetim Okulu: Biçimleşme Okulunun Bütünleştirici Çerçevesi” Akdeniz Üniversitesi IIIBF Dergisi, 3(6): 73-122.

Sabourin, V. (2012) "Through the lenses of strategy execution: Obstacles in engineering management" Leadership and Management in Engineering, 12 (2): 53-59.

Schaap, I. J. (2006) "Toward Strategy Implementation Success: An Empirical Study of the Role of Senior-Level Leaders in the Nevada Gaming Industry" UNLV Gaming Research \& Review Journal, 10 (2): 13-29.

Singh, H. ve Jeffrey, H. D.(1998) "The Relational View: Cooperative Strategy and Sources of Inter Organizational Competitive Advantage" The Academy of Management Review 23(4): 660-679.

Slater, S. F., G. Olson, E. M. ve Hult C. (2010) "Factors influencing the relative importance of marketing strategy creativity and marketing strategy implementation effectiveness, Industrial Marketing Management, 39 (2010) 551-559.

Smith, J. M (1995) "Ethics as excellence: A strategic management perspective"Journal of Business Ethics, 14(8): 683693.

Thompson, A. ve Strickland, A. J. (2003) Strategic management: conceptsandcases,McGraw-Hill/Irwin. 
Varon, E. (2002) "Implementation is not forthemeek" CIO, 16 (4).

Zaribaf, M. ve Bayrami, H. (2010) "An effective factors pattern affecting implementation of strategic plans" Academic and Business Research Institute.

Waititu, J. W. (2016) "Relationship between Strategy Implementation and Performance in Commercial Banks in Nairobi County Kenya" International Journal of Business and Management, 11(9): 230-253. 